\title{
PERAN GURU DI ERA DIGITAL DALAM MENGEMBANGKAN SELF REGULATED LEARNING SISWA GENERASI Z UNTUK PENCAPAIAN HASIL PEMBELAJARAN OPTIMAL
}

\author{
Mardianto \\ Jurusan Psikologi FIP Universitas Negeri Padang (mardiantopsi@ fip.unp.ac.id)
}

\begin{abstract}
Abstrak
Artikel ini mengeksplorasi peran guru di era teknologi digital dalam mengembangkan regulasi diri siswa generasi $\mathrm{Z}$ dalam belajar untuk capaian pembelajaran yang optimal. Metode penulisan artikel ini menggunakan pendekatan kepustakaan dengan mencari referensi teori yang relefan dengan kasus atau permasalahan yang ditemukan. Analisis dilakukan dengan mendeskripsikan konsep dan dinamika teori yang berhubungan dengan masalah, berdasarkan literatur yang tersedia, terutama dari artikel-artikel yang dipublikasikan dalam berbagai jurnal ilmiah. Hasil beberapa kajian menjelaskan bahwa kehadiran teknologi digital saat ini membawa kesenjangan antara guru sebagai digital immigrants dengan siswa sebagai digital natives, sehingga diperlukan pengembangan strategi dan keterampilan guru dalam mengajar, membimbing dan memotivasi siswa agar lebih mandiri dan memiliki self regulated dalam mengatur strategi belajar yang lebih tepat sesuai dengan kebutuhan siswanya saat ini, agar capaian pembelajaran diperoleh secara optimal.
\end{abstract}

Kata Kunci: peran guru, siswa generasi Z, dan self regulation learning.

\begin{abstract}
This paper explores the role of teachers in the digital era to improve self regulated learning of Generation $\mathrm{Z}$ students for optimal learning outcomes. The method of writing this paper uses a library research approach by looking for references to theories that are relevant to the cases or problems found. The analysis is carried out by describing the concepts and dynamics of the theory relating to the problem, based on the available literature, especially from articles published in various scientific journals. The results of several studies explain that the presence of digital technology now brings the gap between teachers as digital immigrants and students as digital natives, so that the development of strategies and skills of teachers in teaching, guiding and motivating students to be more independent and self regulated is needed in managing more learning strategies right according to the needs of current students, so that learning outcomes are obtained optimally.
\end{abstract}

Keywords: teacher's role, generation Z students, dan self regulation learning.

Perkembangan teknologi informasi dan komunikasi membawa perubahan yang sangat besar dalam setiap lini kehidupan masyarakat kita, baik secara budaya, sosial-ekonomi, politik keamanan termasuk pendidikan. Berawal dari perubahan pola komunikasi dan interaksi dalam masyarakat, membawa perubahan pada cara berpikir, bersikap dan berperilaku setiap individu yang menjadi anggota dari masyarakat tersebut. Karena setiap pengalaman yang diperoleh pada setiap era atau zaman akan menentukan bagaimana bentuk perilaku fungsi otak manusia. Teori generasi yang dikemukan oleh sosiolog Karl Mannheim tahun 1923 menjelaskan hubungan perubahan sosial dan pengaruhnya terhadap karakter individu yang hidup di era tertentu (Cilliers, 2017).

Berdasarkan teori itu, para sosiolog yang berkiblat kepada Amerika membagi masyarakat menjadi sejumlah generasi diantaranya; kaum tradisionalis (generasi era depresi, generasi perang dunia II, generasi pasca-PD II), generasi Baby Boomer I, Generasi X,
Generasi Y alias Milenial, dan Generasi Z. Masingmasing kelompok ini sangat berbeda ketika mempertimbangkan nilai, tujuan, dan cita-cita. Setiap generasi baru telah dikaitkan dengan berbagai karakteristik dan sifat yang secara longgar mendefinisikan mereka sebagai kelompok yang kohesif. Karakteristik terkait ini didasarkan pada kondisi ekonomi, norma dan adat istiadat budaya, kemajuan teknologi, dan peristiwa dunia, semuanya membantu membentuk pemikiran dan pandangan masing-masing generasi (Chun dkk., 2016). Menurut Cilliers, (2017) secara karakter di dunia kerja kaum tradisionalis, lahir antara 1928 dan 1944, yang menghargai otoritas dan pendekatan manajemen top-down, sedangkan generasi baby boomer, lahir antara tahun 1945 dan 1965 yang cenderung gila kerja. Generasi X, lahir antara 1965 dan 1979, generasi yang nyaman dengan otoritas dan memandang keseimbangan kehidupan kerja sebagai hal yang penting. Generasi Y, lahir antara 1980 dan 1995 dan yang umumnya tumbuh dalam kemakmuran dan 
memiliki cerdas teknologi. Selanjutnya generasi Z, lahir setelah 1995, yang masih akan memasuki dunia kerja, cenderung mengunakan teknologi digital, pembuat keputusan yang cepat, dan sangat terhubung satu sama lain di dunia daring. Renfro (dalam Chun dkk., 2016) menjelaskan bahwa gerasi $\mathrm{Z}$ saat ini berusia antara lima dan dua puluh tahun, mereka sering disebut sebagai; Digital Natives, Internet Generation (IGen), dan Screensters karena mereka adalah generasi pertama yang lahir di lingkungan yang terhubung dengan internet dan sangat paham teknologi. Kalau di lihat dari rentang perkembangan usia saat ini, generasi $\mathrm{Z}$ adalah para remaja dan para pelajar dalam kategori demografi kita.

\section{Siswa Generasi $\mathbf{Z}$}

Cornu, (2011) dan Rothman, (2016) menjelaskan bahwa siswa generasi $\mathrm{Z}$ memiliki karaterisitik yang berbeda dengan generasi sebelumnya, dalam perilaku belajar dan bagaimana mereka merespons setiap instruksi pembelajaran yang diberikan di kelas. Menurut mereka generasi Z (Gen Zers) bukan hanya pembelajar yang berbeda, tetapi mereka juga memiliki nilai dan tujuan yang berbeda. Kemajuan teknologi digital juga memberikan masalah pada siswa generasi Z, sesuai dengan karakter pada era teknologi digital, semua serba cepat dan instan, individu yang hidup di era ini juga dimanjakan dengan semua fasilitas yang diberikan oleh teknologi digital, sehingga siswa $\mathrm{Z}$ juga terkesan manja memiliki minat yang rendah untuk belajar di sekolah khususnya di kelas yang masih mengunakan pendekatan tradisional dalam pembelajaran. Siswa lebih sibuk dan asik bermain game, membaca dari tablet/gajet miliknya, dan sulit untuk fokus pada papan tulis serta ceramah guru di depan kelas (Duse \& Duse, 2016).

Menurut Nzai, Feng, dan ReYna, (2014) ada kesenjangan generasi antara guru dari generasi Y sebagai digital immigrant dengan siswa generasi $\mathrm{Z}$ sebagai digital native. Siswa gererasi $\mathrm{Z}$ tidak sama dengan siswa generasi sebelumnya, dan mereka merespons instruksi secara berbeda. Guru harus mengubah cara mengajarnya untuk menyelaraskan dengan nilai-nilai dan gaya belajar dari para siswa generasi baru ini. Metode pengajaran, konten instruksional, dan tujuan harus relevan dan menarik bagi mereka, agar proses pembelajran dapat berjalan sesuai dengan visi dan misinya. Sebagaimana dijelaskan sebelumnya, Generasi Zers (Gen Zers) bukan hanya pembelajar yang berbeda, tetapi mereka juga memiliki nilai dan tujuan yang berbeda, dengan demikian, metode pengajaran tradisional mungkin tidak lagi efektif.

\section{Peran Guru dan Sekolah dalam Pembelajaran Siswa}

Dalam proses pembelajaran guru sebagai tenaga berpendidikan memiliki tugas menyelenggarakan kegiatan belajar mengajar, membimbing, melatih, mengolah, meneliti dan mengembangkan serta memberikan pelajaran teknik karena setiap guru harus memiliki kewenangan dan kemampuan profesional, kepribadian, dan kemasyarakatan. Sekolah bukan sekedar tempat untuk berlangsungnya proses transfer ilmu tetapi juga merupakan wadah bagi guru untuk membangun kepribadian peserta didiknya. Sekolah memfasilitasi dan memberikan kemudahan bagi siswa untuk mengembangkan potensi yang dimilikinya dalam mencapai kualitas manusiaannya, baik secara fisik, psikologi sosial dan emosional. Proses belajar-mengajar di sekolah memposisikan siswa sebagai subjek proaktif yang ingin meraih cita-cita, memiliki tujuan, dan kemudian ingin mencapainya secara optimal. Belajar adalah suatu usaha yang dilakukan individu untuk memperoleh perubahan tingkah laku secara keseluruhan, relatif permanen sebagai hasil pengalaman individu dalam interaksi dengan lingkungannya (Israeloff, 2012).

Motivasi siswa yang dipengaruhi oleh perilaku guru memiliki asumsi bahwa dengan mengembangkan hubungan positif guru dengan siswa akan meningkatkan keefektifan instruksional guru dan memberikan pengaruh lebih besar pada pembelajaran siswa. Pembelajaran bekualitas akan dapat dikembangakan secara maksimal dengan strategi yang tepat ketika guru memahami perkembangan siswa, bagaimana siswa belajar, dan startegi pengajaran apa yang efektif dan sesuai untuk digunakan. Hubungan yang positif antara guru dan siswa berkorelasi dengan efektifitas strategi pembelajaran yang akan digunakan dengan ketentuan bahwa untuk membangun hubungan tersebut tidak terlepas dari keterampilan mengajar bahkan merupakan bagian dari keterampilan guru. Sebab guru yang efektif adalah yang membangun hubungan positif saat mereka terlibat dalam proses pembelajaran serta memiliki keyakinan terhadap kemampuan siswanya (Levin \& Nolan, 2014).

Kualitas pembelajaran dapat dimaknai dengan tingkat pencapaian tujuan pembelajaran. Pencapaian tujuan tersebut berupa peningkatan pengetahuan dan keterampilan serta pengembangan sikap melalui proses pembelajaran. Ada banyak aspek yang memepengaruhi kualitas pembelajaran, salah satunya adalah kemandirian belajar. Kemandirian belajar adalah aktivitas kesadaran siswa untuk mau belajar tanpa paksaan dari lingkungan sekitar dalam rangka mewujudkan pertanggungjawaban sebagai seorang pelajar dalam menghadapi kesulitan belajar. Kemandirian belajar siswa dalam konsep psikologi pendidikan disebut dengan self regulated learning.

\section{Self Regulated Learning}


Self regulation merupakan kemampuan seseorang mengatur dirinya dalam pencapaian prestasi di bidang akademik. Self regulation dalam bidang akademik didefinisikan sebagai proses belajar yang terintegrasi, terdiri dari pengembangan perilaku-perilaku konstruktif yang akan mempengaruhi cara belajar individu. Proses ini disusun dan direncanakan untuk mendukung pencapaian tujuan pribadi dalam lingkungan belajar yang menantang (Zimmerman., 2000). Menurut Schunk (2012) self regulation dalam bidang akademik merupakan kemampuan individu dalam menetapkan tujuan belajarnya kemudian mengadaptasikan karakteristik pribadi dengan cara belajar yang sesuai serta pengendalian diri dari godaan belajar untuk mencapai tujuan berupa prestasi dalam bidang akademik.

Self regulated learning adalah proses kognitif mulai dari menghadirkan informasi atau instruksi, memproses dan mengintegrasikan pe ngetahuan dan mengulang informasi. Salah satu faktor keberhasilan self regulation ialah pada proses penetapan tujuan. Oleh karena itu, untuk berhasil dalam self regulation di bidang akademik, pertama-tama individu harus memiliki tujuan untuk meraih prestasi di bidang akademik dan kehidupan lainnya. Kegagalan dalam self regulation seringkali dikaitkan dengan penyimpangan perilaku sosial dan kegagalan dalam bidang akademik. Sehingga bisa disimpulkan bahwa siswa yang tidak mampu meregulasi dirinya cenderung memiliki tingkat prestasi yang rendah dibanding dengan potensi yang dimilikinya (Salovaara, 2005).

Perkembangan teknologi digital mustinya membantu dan memudahkan siswa dalam belajar, namun kenyataanya kecanggihan tersebut justru membuat mereka malas untuk membaca materi palajaran pada buku teks karena materi tersebut bisa diperoleh dari internet dan langsung dapat mengkopi pastenya tanpa harus membeli dan membaca buku atau tulisan tersebut untuk memahami lebih dalam isi dari materi yang dibahas dan disajikan. Hal ini tentu saja akan berakibat pada perilaku belajar dan penurunan minat baca dari siswa, selain itu dengan adanya media sosial yang beragam versi karakteristiknya makin menambah kemalasan siswa dan akan membuat membuat siswa semakin ketergantungan dengan gajet mereka. Bahkan tidak jarang ketika mereka berniat untuk mengerjakan tugas sekolah, dan mereka sudah membuka internet mereka pasti tidak lupa untuk sekedar mengeceks isi akun media sosialnya. Selain itu dalam beberapa kasus didapati siswa juga malas untuk pergi ke sekolah karena mereka berfikir buat apa mereka ke sekolah jika pelajaran yang seharusnya didapat di sekolah, mereka dapat temukan di youtube dan beberapa aplikasi di internet yang memberikan program, seperti e-Learning dalam pembelajaran yang memudahkan mereka untuk memehamim setiap materi yang dapat diakses kapan saja dan dimana saja

Artikel ini membahas tentang pengaruh perkembangan teknologi informasi dan komunikasi serta tantangan yang dihadapi oleh guru sebagai digital immigrants dalam menjalankan peran dan fungsinya secara efektif pada pembelajaran untuk siswa generasi $\mathrm{Z}$ sebagai digital natives. Agar lebih sistemasit artikel ini akan memaparkan bagaimana teknologi dan system digital mempengaruhi karakteristik perkembangan anak dan remaja khususnya siswa di era revolusi industry 4.0 ini.

\section{METODE}

Metode penulisan artikel ini menggunakan pendekatan kepustakaan atau kajian literatur dengan mengeksprolasi berbagai teori, prinsip, atau gagasan yang digunakan untuk menganalisis dan memecahkan permasalahan yang dirumuskan di latar belakang. Data yang digunakan dalam penelitian ini adalah data sekunder yaitu data yang diperoleh dari hasil penelitian yang telah dilakukan oleh peneliti-peneliti terdahulu. Sumber data diperoleh dari buku dan karya ilmiah yang dipublikasikan pada jurnal (tercetak dan/atau non-cetak) yang berhubungan dengan masalah yang menjadi bahasan dalam paper ini.

Artikel ini mengunakan analisis deskriptif, yaitu memaparkan secara sistematis dinamika konsep dan permaslahan, kemudian diberikan pemahaman dan penjelasan agar dapat dipahami dengan baik.

\section{HASIL DAN PEMBAHASAN}

Setiap generasi baru selalu dihubungkan dengan berbagai karakteristik dan sifat yang secara umum mendefinisikan mereka sebagai sebuah kelompok sosial yang kohesif satu sama lainnya. Karakteristik tersebut berkembang berdasarkan kondisi ekonomi, norma adat istiadat dan budaya, serta kemajuan teknologi, ataupun sebuah peristiwa, yang semuanya membantu membentuk pola pikir dan pandangan masing-masing generasi. Perkembangan teknologi informasi dan komunikasi serta digitalisasi yang luar biasa saat ini melahirkan sebuah kelompok generasi digital (digital native), yaitu internet generation (IGen), atau generasi internet, karena mereka adalah generasi pertama yang lahir dan hidup di lingkungan yang terhubung dengan internet dan sangat paham teknologi tersebut.

Secara tahapan perkembangan dan rentang usia generasi ini adalah sebagai pelajar yang aktif mulai dari tingkat sekolah dasar, sekolah menengah, sampai pendidikan tinggi. Mereka hidup di lingkungan digital, pengalaman hidup mereka dibentuk oleh pengalaman 
dengan teknologi digital, mereka larut dalam teknologi, dan mereka menggunakan alat-alat digital secara natural, tanpa memikirkan sifat dan karakteristik cara kerjanya. Otak mereka beralih secara spontan ke dunia digital, teknologi digital hadir secara alami, sehingga membentuk pribadi dan karakteristik mereka. Hal ini tentunya juga berdampak pada perkembangan dunia pendidikan kita terutama dalam hal, perencanaan dan strategi pembelajaran untuk siswa generasi internet ini atau sering juga disebut sebagai generasi $\mathrm{Z}$.

Generasi $\mathrm{z}$ sebagai digital native lebih mengandalkan kecepatan dalam menggunakan dan menerima informasi, ingin segera mendapatkan informasi, sehingga kurang mentolerir hal-hal yang bersifat lambat. Sehingga cenderung memproses informasi dengan jalan nonlinear, melompat lompat dari tugas satu ke tugas yang lain, multitasking, dan lebih mudah memahami gambar daripada teks. Selain itu mereka lebih menyukai belajar melalui aktifitas praktek langsung daripada membaca atau mendengarkan. Lebih suka dan mampun bekerja sama dalam jejaring, karena merasa teknologi adalah bagian dari kehidupannya, sehingga merasa kesulitan dan tidak nyaman tanpa adanya teknologi di sekitar mereka dan selalu menginginkan mendapatkan manfaat/penghargaan segera atau serba instant.

Menurut (Chun dkk., 2016) beberapa penelitian mengilustrasikan bahwa otak Generasi Z secara struktural berbeda dari generasi sebelumnya, hal tersebut terjadi bukan sebagai hasil dari genetika, tetapi sebagai hasil dari lingkungan eksternal dan bagaimana otak kita meresponsnya. Otak Generasi Zs telah terhubung dengan pencitraan visual yang canggih dan kompleks, sehingga akibatnya bagian otak yang bertanggung jawab atas kemampuan visual jauh lebih berkembang, membuat bentuk-bentuk pembelajaran visual yang lebih efektif. Pembelajaran yang hanya mendengarkan, seperti ceramah dan diskusi, sangat tidak disukai, sedangkan permainan interaktif, proyek kolaborasi, penyelenggara tingkat lanjut, dan tantangan menjadi bagian dari keinginan mereka (Rothman, 2016). Ini juga berlaku untuk lingkungan pendidikan tinggi di mana mahasiswa Generasi $\mathrm{Z}$ mengandalkan rekaman PC daripada mencatat, lebih cenderung untuk mengajukan pertanyaan secara online, melihat kuliah sebagai "datang dan hiburan aku" (come and entertain me) dan tidak suka menunggu tanggapan tetapi menuntut informasi dan komunikasi instan. Sehingga strategi dan metode pengajaran tradisional selama ini digunakan mungkin tidak lagi efektif.

Prinsip dasar pengelolaan kelas agar dapat bejalan secara maksimal didasarkan pada wawasan dan pengetahun guru tentang potensi, gaya dan cara belajar peserta didiknya, sehingga dapat menetukan strategi pengajaran yang tepat dan efektif pada setiap kelas pembelajaran. Guru juga mempunyai fleksibilitas yang tinggi yaitu pendekatan dedikatif dan gaya manajemen kelas yang selalu disesuaikan dengan keadaan, situasi kelas yang diberi pelajaran, sehingga dapat menunjang tingkat prestasi siswa semaksimal mungkin. Siswa yang tidak mampu melakukan pembagian waktu yang baik bisa menimbulkan kelalaian didalam melaksanakan tugas kewajiban seorang siswa yaitu belajar, karena terlalu asik internetan. Oleh karena itu, guru musti senantiasa mengingatkan siswa untuk dapat memanfaatkan internet kepada yang positif dan dapat mengatur waktu pengunaanya.Ketika siswa tidak mampu membagi waktunya dengan baik, maka akan terjadi kekacauan didalam belajarnya. Hal ini akan memberikan dampak negatif terhadap prestasinya, jika siswa tidak memiliki kemampuan self regulated learning.

Menurut Santrock., (2011) self regulated learning adalah kemampuan mandiri siswa dalam mengendalikan dan memonitor sendiri pikiran, perasaan, dan perilaku untuk mencapai suatu tujuan dalam proses belajar. Tujuan tersebut dapat berupa tujuan akademik seperti; meningkatkan pemahaman dalam membaca, menjadi penulis yang baik, belajar berhitung atau matematika yang benar, atau kemapuan mengajukan pertanyaan yang relevan. Selain itu tujuan lainnya adalah kontrol sosio-emosional yaitu kemamupan mengontrol kemarahan, belajar bersama dengan teman sebaya. Belajar meregulasi diri dengan memiliki karakteristik yang bertujuan untuk memperluas pengetahuan dan menjaga motivasi, menyadari keadaan emosi mereka dan punya strategi untuk mengelola emosinya, secara periodik memonitor kemajuan ke arah tujuannya, menyesuaikan atau memperbaiki strategi berdasarkan kemajuan yang mereka buat, dan mengevaluasi halangan yang mungkin muncul dan melakukan adaptasi yang diperlukan. Self regulated learning adalah proses aktif dan konstruktif siswa dalam menetapkan tujuan untuk proses belajarnya dan berusaha untuk memonitor, meregulasi, dan mengontrol kognisi, motivasi, dan perilaku, yang kemudian semuanya diarahkan dan didorong oleh tujuan dan mengutamakan konteks lingkungan. Siswa yang mempunyai self regulasi learning tinggi adalah siswa yang secara metakognitif, motivasional, dan behavioral merupakan peserta aktif dalam proses belajar.

Self regulation dalam bidang akademik akan membantu siswa dalam menetapkan cara belajar paling efektif untuk diri sendiri yang diperoleh dari observasi yang cermat dalam mengamati perilaku diri dan kegiatan serta konsekuensinya. Dalam hal ini siswa diminta untuk secara konsisten berusaha mengendalikan dan mengurangi perilaku negatif dan meningkatkan atau memperbanyak perilaku yg lebih positif untuk pencapaian tujuan akademik yaitu prestasi belajar. 
Kemampuan individu dalam mengatur dirinya dalam bidang akademik dapat diukur dari tiga kategori yaitu :

a. Kemampuan pribadi; Strategi ini melibatkan kemampuan individu dalam mengorganisasikan dan menginterpretasikan informasi. Kemampuan ini meliputi :

1) Mengorganisasi dan mengelola informasi, dimana saat menerima informasi, apakah informasi melalui proses belajar mengajar maupun informasi yang diperoleh dari berbagai sumber (misalnya buku, jurnal dan internet), individu harus mampu mencari ide pokok, membuat meringkas, menyusun kembali materi, menggarisbawahi hal-hal yang penting, mengorganisasikan pencatatan (menggunakan flash card/ indekx card), memanfaatkan gambar, diagram, bagan maupun melakukan pemetaan kognitif.

2) Merencanakan tujuan dan standar, dalam hal ini individu atau siswa mampu menyusun perencanaan yang melibatkan waktu yang dibutuhkan dan mengatur jadwal.

3) Membuat catatan dan monitoring dalam hal ini siswa sebagai individu harus tetap melakukan pencatatan (misalnya membuat daftar masalah, kesalahan-kesalahan dan hal-hal yang penting) dan monitoring. Catatan tersebut harus disimpan dan disusun dalam sebuah sistem sehingga mudah ditemukan saat diperlukan.

4) Mengingat dan mengulang informasi yaitu individu dapat menerapkan berbagai strategi mengingat dan mengulang kembali materi yang diterima untuk mengeliminir efek lupa. Beberapa strategi mengingat yang dapat dilakukan antara lain menemonic, mengulangulang, berdiskusi dengan orang lain, mengajarkannya pada orang lain, dll.

b. Perilaku; Kemampuan ini melibatkan kegiatankegiatan yang dilakukan individu antara lain :

1) evaluasi diri meliputi kemampuan melakukan checking pada kualitas dan kemajuan yang diperoleh. Termasuk di dalamnya ialah kemampuan melakukan analisis tugas, memerintah diri sendiri dan mengobservasi kegiatan yang dilakukan.

2) self consequating Meliputi kemampuan untuk memotivasi diri, menyusun sendiri hukuman atau konsekuensi bilamana keluar dari perencanaan atau lalai terhadap godaan, dan menunda pemuasan kebutuhan.

c. Lingkungan; Kemampuan ini meliputi kesanggupan mencari bantuan dan mengubah lingkungan fisik bilamana diperlukan dalam mencapai tujuan. Kemampuan ini meliputi :

1) Kesanggupan mencari informasi dari lingkungan seperti memanfaatkan perpustakaan, internet, membaca kembali catatan dll.

2) Kesanggupan mengusahakan lingkungan fisik yang nyaman untuk belajar seperti menyusun setting fisik yang menarik, meminimalkan gangguan, dan sanggup beristirahat.

3) Kesanggupan mencari bantuan, baik mencari bantuan melalui teman, guru, senior, yunior dan sebagainya. Kesanggupan mencari bantuan ini sangat terkait dengan kemampuannya menjalin relasi sosial dengan orang lain.

Hal yang paling mendasar saat ini adalah kesadaran dari guru bahwa siswa yang diajarnya saat ini adalah generasi yang jauh berbeda dengan generasinya, yang memiliki pola dan gaya belajar yang tentunya juga berbeda. Sebagian besar guru tidak mengerti apa dan bagaimana strategi belajar yang lebih sukai oleh siswanya, hanya sedikit yang menyadari adanya kesenjangan komunikasi antar mereka, sehingga nyaris tidak ada upaya untuk menjembatani kesenjangan tersebut. Guru yang kreatif akan berpikir bahwa ada kebutuhan yang mendesak untuk mengeksplorasi dan memahami elemen-elemen teknologi, media sosial dan jejaring sosial yang digunakan siswa dan memasukkan elemen-elemen tersebut ke dalam proses pengajaran dan pembelajaran. Hal Ini tidak hanya sekedar mengintegrasikan teknologi sebagai bagian dari belajarmengajar, tetapi juga mencari pengaturan kelas kreatif dengan inisiatif unik yang memperkenalkan lebih banyak metode pengajaran visual dan menarik. Pembelajaran yang berpusat pada siswa memiliki kekuatan dan kemajuan teknologi dan media sosial dapat lebih meningkatkan pendekatan seperti itu. Namun, guru perlu berpikir kritis dan kreatif dan membangun lingkungan kelas yang kondusif untuk berpikir kreatif dan inovatif.

Mengakses pengetahuan baru, koneksi dalam jejaring dan mengembangkan kecerdasan kolektif merupakan tiga aspek utama dari perilaku masyarakat digital natif. Pengetahuan untuk era digital tidak sesuai lagi dengan kurikulum tradisional yang hanya terdiri dari daftar materi yang dibatasi oleh sumber ajar yang sempit. Pengetahuan saat ini lebih kompleks, lebih holistik, dan berkembang sangat cepat. Pengetahuan tidak hanya disimpan dalam ensiklopedia dan buku pelajaran. Pengetahuan terjadi ketika ada masalah yang harus dipecahkan, dan pertanyaan yang harus dijawab. Guru tidak lagi memonopoli sumber pengetahuan, karena internet menyediakan akses ke sejumlah sumber informasi yang lebih luas. Walaupun begitu informasi, 
berbeda dari pengetahuan, karena informasi harus diproses, sesuai dengan konteks siswa agar dapat mengarahkan perkembangan bangunan pengetahuan yang dikonstruksi oleh siswa. Informasi harus diklasifikasikan, disortir, diperiksa, diorganisir.

Siswa generasi $\mathrm{Z}$ sebagai penduduk asli digital (digital native) memiliki pendekatan empiris untuk belajar yang kadang-kadang membingungkan guru atau orang tua. Mereka tidak mengakses pengetahuan secara linear, penalaran demonstratif, dan urutan logis, tetapi mereka mengakses pengetahuan dalam proses acak dan melalui pendekatan "hypertext". Penduduk asli digital memiliki cara yang berbeda dalam berkonsentrasi dan memberikan perhatian yang penuh. Umumnya mereka tidak dapat berkonsentrasi untuk waktu yang lama, mereka berpindah dari satu tugas ke tugas lainnya dalam waktu yang sangat singkat, bahkan cederung multitasking, atau melakukan beberapa tugas secara bersamaan secara paralel, atau berpindah dari satu tugas ke tugas lainnya. Siwa generasi $\mathrm{Z}$ sebagai digital native lebih suka belajar melalui visual dan grafik daripada membaca teks. Mereka terbiasa belajar melalui interaktivitas dan permainan, dan saling terhubung secara permanen satu sama lain, karena pengetahuan ada dalam konektivitas. Mereka terbiasa dengan sejumlah besar informasi dan harus belajar cara mengatasi dan mengendalikannya. Selain itu siswa generasi $\mathrm{Z}$ adalah penguna jejaring dan merupakan "peselancar" paling handal, yang berarti bahwa belajar tidak hanya kegiatan individu, tetapi juga kegiatan kolektif (Cornu, 2011).

Berdasarkan karateristik tersebut pendidik kita sudah tidak bisa lagi menerapkan gaya pendidikan generasi kemarin kepada siswa generasi masa depan. Para siswa telah berubah secara drastis dan karenanya, kita harus menemukan cara baru untuk mengajar yang sesuai untuk generasi Z. Pembelajaran harus mempertimbangkan cara-cara terbaru dalam mengembangkan kemampuan berpikir dan memproses informasi siswa generasi digital. Teori belajar yang sudah ada harusnya dipertimbangkan kembali sesuai dengan tuntutan dan kebutuhan siswa, pendekatan konstruktivis, pembelajaran kolaboratif, dan jejaring untuk pembelajaran sangat direkomendasikan oleh beberapa ahli pedagogi memiliki perhatian terhadap perkembangan dunia pendidikan saat ini. Sesuai dengan karakternya siswa generasi $\mathrm{Z}$ lebih menyukai gaya belajar mengunakan pendekatan eksperimen (learning by doing), mengunakan media pembelajaran yang berupa audio visual (visual learning), senang bekerja dalam tim dengan rekan, menggunakan alat kolaboratif seperti Google Apps, sulit untuk konsentrasi atau fokus pada satu kegiatan dalam waktu yang lama. Mereka lebih senang belajar dengan santai dan enjoy pembelajaran yang menyenangkan dan menghibur atau yang disebut dengan edutainment(Mohr \& Mohr, 2017).

Sekolah saat ini hampir tidak cocok dengan generasi digital native, karena strategi pembelajaran, manajemen kelas, dan evaluasi yang dilakukan, serta hubungan yang dibangun antara siswa, guru, mengalami kesenjangan harus dijembatan. Sekolah masa kini bukan bersifat digital native, sekalipun telah mengintegrasikan cukup banyak teknologi baru, dan para gurunya, secara umum adalah imigran digital. Mereka harus memperhitungkan perbedaan besar antara mereka dan siswanya. Walaupun begitu guru juga seharusnya tidak perlu berpura-pura menjadi penduduk asli digital, mereka cukup berpegang teguh pada peran penting dari seorang guru, sebagai fasilitator yang penyelenggarakan interaksi antara siswa dengan pengetahuan, dan sebagai mediator pengetahuan.

Proses pembelajaran dinyatakan berhasil apabila learning out comes, atau dalam istilah lain juga dikenal sebagai Tujuan Intruksional Khusus (TIK) dari bahan pengajaran (materi pengajaran) tersebut dapat dicapai (Slavin, 2018). Tujuan Intruksional Khusus (TIK) dari bahan pengajaran (materi pelajaran) yang ingin dicapai. Walapun secara prosesnya pembelajaran di era digital menuntut siswa untuk aktif berkolaboratif sesame peserta didik, dan semua kegiatan berposat pada siswa atau student centre, tetap saja peran guru sangat dibutuhkan agar tujuan pembelajaran tetap berjalan dengan semestinya. Self regulated learning siswa perlu difasilitasi guru agar penerapanya berjalan dengan semestinya. Penerapan strategi self regulated learning menurut Zimmerman (2000) secara khusus learning dalam mengajar dibagi menjadi tiga tahapan, yaitu:

1) Forethought (pemikiran), sebelum pelaksanaan pembelajaran, guru mempersiapkan pengajaran mereka, menetapkan tujuan pengajaran, rencana tindakan mereka, mengatur strategi pembelajaran dan bahan ajar yang lebih luas baik offline maupun online dengan digital literasi yang bersifat audio visual. Forethought, tahapan pertama yang merupakan proses berpikir, guru mengajak siswa mencermati topik pembelajaran yang akan diajarkan, kemudian guru mengarahkan siswa untuk menganalisa bagian terpenting dari materi dan mengkaitkannya dengan materi sebelumnya. Siswa membentuk membentuk kelompok belajar yang beranggotakan 4 sampai 5 anggota.

2) Performance (kinerja), selama instruksi di kelas, guru memantau pemahaman siswa, mengidentifikasi dan menyelesaikan kesalah pahaman. Tahap performance, siswa memecahkan permasalahan dengan mengaplikasikan informasi 
yang telah didapatkan pada tahap forethought. Kemudian guru mendiskusikan masalah-masalah yang tidak terpecahkan serta mengarahkan siswa untuk berdiskusi. Siswa mempresentasikan jawaban dari pekerjaannya didepan kelas, mengunakan media teknologi presentasi yang kreatif dan inovatif.

3) Self Reflection (refleksi diri), guru mengevaluasi efektivitas instruksi mereka dan strategi pengajaran yang digunakan, serta mengevaluasi pemahaman siswa dari pengertian pengetahuan yang dikonstruksikan secara bersama. Self Reflection, adalah tahap dimana siswa mengevaluasi pemahamannya selama proses pembelajarannya. Kemudian siswa mendiskusikannya kembali dengan teman ataupun guru untuk memperbaiki pemahamannya yang masih kurang ketika kegiatan pembelajaran. Untuk selanjutnya siswa membuat kesimpulan dari apa yang telah dipelajari selama pembelajaran belangsung.

Tjalla (2015) menjeaskan self regulated learning yang terdiri dari pemikiran, perasaan dan tindakan yang dihasilkan sendiri yang direncanakan dan disesuaikan dengan pencapaian tujuan peserta didik dengan mendukung peserta didik dalam mengoptimalkan proses belajar mereka. Oleh karena itu, SRL memiliki dampak positif pada hasil belajar dan kesejahteraan. Dari penjelasan diatas dapat ditarik kesimpulan bahwa peserta didik yang mempunyai self regulated learning pasti mempunyai tujuan pembelajaran yang baik dengan begitu hasil belajar sejarah mereka juga baik karena di dukung oleh strategi tujuan pembelajaran yang telah mereka buat.

Siswa yang memiliki kemandirian belajar yang tinggi akan berusaha menyelesaikan segala latihan atau tugas yang diberikan oleh guru dengan kemampuan yang dimilikinya sendiri. Sehingga secara tidak langsung akan mempengaruhi kualitas pembelajaran. Sejalan dengan pemikiran di atas Latipah., (2010) dalam artikelnya meta analisisnya menemukan bahwa dari 3899 subyek menunjukkan bahwa strategi belajar mandiri diatur berkorelasi positif dengan prestasi akademik $(r=0,26)$. Perbedaan dalam varians korelasi dapat, antara lain, disebabkan oleh kesalahan sampling $(4,63 \%)$ dan kesalahan dalam pengukuran independen serta variabel dependen $(4,44 \%)$. Secara keseluruhan hasil penelitian menunjukkan bahwa strategi self regulated learning berpengaruh positif terhadap prestasi akademik siswa.

Pada akhirnya siswa generasi $\mathrm{Z}$ mengingikan lingkungan dan strategi pembelajaran yang dekat dengan keseharian dunia digital mereka. Hal ini mengisyaratkan kebutuhan sekolah kususnya guru untuk mengembangkan kemampuan dalam mengeksplorasi dan memahami elemen-elemen teknologi, media sosial dan jejaring sosial yang dikuasai siswa dan memasukkan elemen-elemen tersebut ke dalam pengajaran dan pembelajaran. Selain itu usaha untuk mencari pengelolaan kelas yang lebih kreatif dengan memperkenalkan media pengajaran audio visual dan menarik, serta metode pembelajaran yang berpusat pada siswa. Sehingga segala upaya yang dikembangkan dapat mengakomodasi kebutuhan pengembangan keterampilan regulasi diri siswa Generasi $\mathrm{Z}$ dalam belajar dan menguasai setiap materi yang diberikan.

\section{PENUTUP}

\section{Simpulan}

Perkembangan teknologi dan akses informasi yang begitu cepat di era digital ini memungkinkan peserta didik lebih dahulu mendapatkan informasi terlebih dahulu para gurunya. Tentu hal ini tidak akan membuat guru menjadi ketinggalan dibanding siswanya. Namun demikian, teknologi informasi dan komunikasi, media sosial ataupun media lainnya yang ada di dunia maya hanyalah instrument pendidikan dan bukan tujuan. Media atau pun instrument tidak dapat mengantikan peran guru dalam proses pembelajaran sebab media tidak mempunyai sisi kemanusiaan, oleh sebab itu kehadiran guru secara emosional sangat penting untuk menumbuh kembangkan sisi kemanusiaan seorang siswa dan mengendalikan gejala impulsif karakter yang ada dalam diri siswa generasi $\mathrm{Z}$ yang di pengaruhi oleh lingkungan digital nativenya sehingga merugukan siswa itu sendiri. Profesional seorang guru ditengah-tengah kemajuan teknologi informasi dan komunikasi dalam proses pembelajaran di Era Digital tetap sangat dibutuhkan karena keberadaan guru di kelas dan lingkungan sekolah lebih kepada memfasilitasi siswa untuk belajar, agar siswa dapat mengatur strategi belajarnya dan self regulated learning untuk tetap memberikan kontribusi dalam meningkatkan motivasi belajar dan meningkatkan hasil pencapaian dari proses belajar yang dilakukan. Siswa yang memiliki kemandirian belajar yang tinggi akan berusaha menyelesaikan segala latihan atau tugas yang diberikan oleh guru dengan kemampuan yang dimilikinya sendiri. Sehingga secara tidak langsung akan mempengaruhi kualitas pembelajaran.

\section{DAFTAR PUSTAKA}

Chun, C., Kelley Dudoit, M., Shirl Fujihara, K., Mariana Gerschenson, J. A. A. K., Koanui, B., \& Stearns, C. J. (2016). Teaching Generation $Z$ at the University of Hawai ' $i$.

Cilliers, E. J. (2017). The challenge of teaching 
generation Z. International Journal of Social Sciences, 3(1, January), 188-198.

Cornu, B. (2011). Digital Natives: How do They Learn? How to Teach Them? In Policy Brief. Moscow: Published by the UNESCO Institute for for Information Technologies in Education 8 Kedrova St., Bldg. 3.

Duse, C. S., \& Duse, D. M. (2016). The Teacher of the Generation Z. Romania: Future Academy www.FutureAcademy.org.uk.

Israeloff, J. M. L. and R. (Ed.). (2012). Philosophy and Education, Introducing Philosophy to Young People. In Philosophy and Education, Introducing Philosophy to Young People. Cambridge Scholars Publishing 12.

Latipah, E. (2010). Strategi Self Regulated Learning dan Prestasi Belajar : Jurnal Psikologi, 37(1), 110-129.

Levin, J., \& Nolan, J. F. (2014). Principles of Classroom Management: A Professional Decision-Making Model (7nd ed.). Boston, MA: Allyn and Bacon.

Mohr, K. A. J., \& Mohr, E. S. (2017). Understanding Generation Z Students to Promote a Contemporary Learning Environment. Journal on Empowering Teaching Excellence, 1(1), 84-94.

Nzai, V. ekiaka, Feng, Y., \& ReYna, C. (2014). Preparing Net Gen pre-service teachers for digital native classrooms. Applied, Colombian Journal, Linguistics, 16(2), 185-200.

Rothman, D. (2016). A Tsunami of Learners Called Generation Z.

Salovaara, H. (2005). Achievement Goals and Cognitive Learning Strategies in Dynamic Contexts of Learning. University of Oulu.

Santrock, J. W. (2011). Educational Psychology (Fifth). New York, NY 10020: McGraw-Hill Humanities.

Schunk, D. H. (2012). Learning Theories An Educational Perspective (Sixth Edit). Boston, MA, 02116: Pearson Education, Inc.

Slavin, R. E. (2018). Educational Psychology. NY, NY: Pearson Education, Inc.

Tjalla, A. (2015). Effect of Methods of Learning and Self Regulated Learning toward Outcomes of Learning Social Studies. Journal of Education and Practice, 6(23), 15-21.

Zimmerman,B.J., Schunk, D.H. (2000). Handbook of Self Regulation. Guilford Press : New York. 